\title{
Secondary mitral regurgitation according to gender
}

\author{
CMarko Perčić1 ${ }^{*}$, \\ ¿CZrinka Planinić', \\ (1)Ante Pašalić', \\ -Tea Friščić', \\ DDario Gulin', \\ (CLeon Adrović', \\ (DDijana Bešić', \\ (1DJozica Šikić1,2
}

'University Hospital "Sveti Duh", Zagreb, Croatia

2University of Zagreb School of Medicine, Zagreb, Croatia
RECEIVED:

April 24, 2018

ACCEPTED:

May 10, 2018

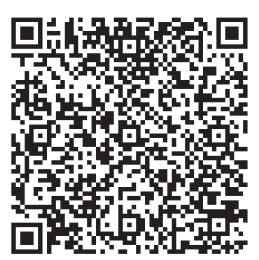

KEYWORDS: secondary mitral regurgitation, gender

CITATION: Cardiol Croat. 2018;13(5-6):184. | https://doi.org/10.15836/ccar2018.184

*ADDRESS FOR CORRESPONDENCE: Marko Perčić, Klinička bolnica "Sveti Duh“, Sv. Duh 64, HR-10000 Zagreb, Croatia. / Phone: +385-91-3712-531 / E-mail: markopercicmef@gmail.com

ORCID: Marko Perčić, https://orcid.org/0000-0001-7904-8899 • Zrinka Planinić, https://orcid.org/0000-0001-8664-3338 Ante Pašalić, https://orcid.org/0000-0001-5989-6495 • Tea Friščić, https://orcid.org/0000-0003-3189-8661 Dario Gulin, https://orcid.org/0000-0001-8502-7816 • Leon Adrović, https://orcid.org/0000-0002-0555-6863 Dijana Bešić, https://orcid.org/0000-0001-9701-0253• Jozica Šikić, https://orcid.org/0000-0003-4488-0559

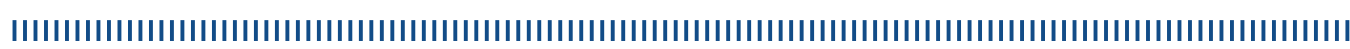

Background: Mitral regurgitation (MR) represents the second most common valvular heart disease $(\mathrm{VHD})^{1}$. It is classified as primary (organic) and secondary (functional) MR, with secondary being more frequent ${ }^{2}$. Secondary MR is usually result of dilatative cardiomyopathy, ischemic heart disease, postmyocarditis and similar ${ }^{2}$. Its prevalence is approximately $1.6 \%$ to $19.4 \%$, and is associated with worse prognosis than primary ${ }^{3}$. The aim of our study was to investigate the incidence of secondary MR according to gender.

Patients and Methods: Retrospective study was conducted to assess the relation between MR with other VHD. A total of 686 patients, with male predominance of 55\%, were included in the study.

Results: Among all patients with MR 167 (24.3\%) had secondary MR. The main cause was left ventricular enlargement with mitral annular dilatation, counting for 96 ( $57.5 \%$ of secondary MR patients and $14.0 \%$ of all MR patients). Other causes of secondary MR included ischemic and postmyocarditis causes, with frequency of 64 (38.3\% of secondary MR patients and 9.3\% of all MR patients) and 7 (4\% of secondary MR patients and $1 \%$ of all MR patients), respectively. According to gender distribution, 99 (59.3\%) males and 68 (40.7\%) females had secondary MR. Dilatative cardiomyopathy was the main cause of secondary MR in both men and women (60.6\% and 52.9\%). Ischemic MR was present in 36 (36.4\%) men, 28 (41\%) women, while postmyocarditis MR was observed in $3(3 \%)$ of men and $4(5.8 \%)$.

Conclusion: Secondary MR presents high proportion of all MR causes. Dilatative cardiomyopathy was most common cause of secondary MR, regardless of gender groups, with men more affected. Ischemic cause was slightly more common in women than men.

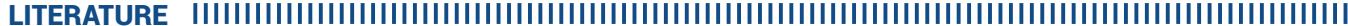

1. Andell P, Li X, Martinsson A, Andersson C, Stagmo M, Zöller B, et al. Epidemiology of valvular heart disease in a Swedish nationwide hospitalbased register study. Heart. 2017 Nov;103(21):1696-1703. https://doi.org/10.1136/heartjnl-2016-310894

2. Okura H, Kataoka T, Yoshida K. Renin-angiotensin system inhibitors in patients with myocardial infarction and secondary mitral regurgitation Heart. 2016 May:102(9):694-700. https://doi.org/10.1136/heartjnl-2015-308536

3. Agricola E, Oppizzi M, Pisani M, Meris A, Maisano F, Margonato A. Ischemic mitral regurgitation: mechanisms and echocardiographic classification. Eur J Echocardiogr. 2008 Mar;9(2):207-21. https://doi.org/10.1016/j.euje.2007.03.034 